\title{
The Influence of People Demand Oriented Social Governance and Organi- zations Based on the Theory of Risk Society
}

\author{
Feihu Li* \\ Chongqing City Management College, Chongqing 401331, China
}

\begin{abstract}
This paper explores the influence of people demand oriented social governance and organizations based on the theory of risk society. In the data acquirement and collection phase, the author combined the research methodologies of literature review, quantitative survey, individual interview and etc., then, the data have been analysed by software such as SPSS and EXCEL. After summarizing and modifying, the essay is structured with the thread of raising the problem, describing the problem, and the corresponding solution of the problem.
\end{abstract}

Keywords: Social governance and organizations, SPSS and EXCEL, the people demand oriented, theory of risk society.

\section{INTRODUCTION}

China intervened in the wave of world globalization taking the great unprecedented social practice form socialist market economy in early 1994s. The contemporary China in the trend of globalization is in a critical period of social transformation and accelerating industrial modernization. A series of deep social conflicts is caused by industrial modernization and risk issues of innovation highlight in front of us. Objectively, these social conflicts and risk issues require us to make innovation of our social governance. In the Party's third Plenary Session of the eighteen, the innovation of social governance system was put forth to ensure that people live in peace and society is in stability and good order. This fully demonstrates our party attaches great importance to social governance and its innovation issues. In a certain sense, China's reform and development has entered new historical stage of strengthening and improving social governance to promote social development and other aspects of development. Although the party and government attach great importance to social governance innovation issues, how to carry out social governance innovation is a reality of our current problems to be solved. In recent years, social governance innovation has become a hot academic research. However, overviewing the relevant academic research, most scholars interpret Chinese social governance innovation bounded by historical, domestic horizon which is necessary, but this alone is not enough. Without taking the broad perspective of world globalization, it will be difficult to clearly understand the plight of Chinese social governance innovation in context of globalization and hard to understand their deep implication and path selection $[1,2]$.

Therefore, the interpretation of Chinese social governance innovation from a new global perspective-the theory of risk society not only is the weaknesses of domestic academic research, but also a new horizon of the research of social governance innovation [3]. Guided by Governance methodology and taking beneficial enlightenment to our country. We should inspect this issue from the horizon of the theory of risk society and especially make a deep analysis of its causes of plight form the global risk society perspective. Thus, a new path to the current social governance innovation in our society is proposed [4].

The Social Governance Innovation in China is inspected from the new horizon of the theory of global risk society. The background the theory proposed is investigated. It was proposed in late 1950s when a series of crisis phenomena such as the energy crisis, resource crisis, social crisis, the ecological crisis, nuclear crisis and so on occurred. Theoretical connotations of the theory are as follows: the risks of contemporary society are artificial, manufactured from the perspective of its sources and manifestations; From the perspective of the scale, scope, extent of the risks, it is of a global nature and we are in the global risk society; From the perspective of historical changes of risks, it is a product of modernization, with the duality; From the perspective of how to deal with the risk, it shows a strong institutional tendencies and cultural reflection colour [5-7]. The basic features of the risk society are global, endogenous, holistic, transformative, duality and the long-termed. Theoretical connotations of the theory are as follows: the risks of contemporary society are artificial, manufactured from the perspective of its sources and manifestations; from the perspective of the scale, scope, extent of the risks, it is of a global nature and we are in the global risk society; From the perspective of historical changes of risks, it is a product of modernization, with the duality; From the perspective of how to deal with the risk, it shows a strong institutional tendencies and cultural reflection color. The basic features of risk society are global, endogenous, holistic, transformative, duality and the long-termed. The nations in the world began a new energy research and development, scrambled for international resources, adjusted social policy, carried out environmental movement and established an international nuclear 
non-proliferation regime. The implications for China's social governance innovation philosophy, to build a are to face the reality of risk, to establish a modern risk "reflexive" enhance the sense of responsibility society, to take the initiative to resolve risks; to of society members, to promote mutual trust in social governance; to actively improve community governance, to evade risk brought about by globalization [8].

\section{THE BASIC MODEL AND CURRENT SITUATION OF RISK SOCIETY}

This paper analyses the plight of China's social governance innovation under the horizon of the theory of risk society. These difficulties are embodied in: First, the structural risks of social governance innovation grow and spread, mainly the high tensioned social structure, prominent social polarization, obvious unfair allocation of risk, diversification of conflicts of interest brought about by the risk, the complex nature of risks intertwined with sudden, multiple and high destructive of risks paralleling; Secondly, The "involution" phenomenon of it highlighted. By analysing the "Internalization" concept and its application, we may find this phenomenon shows in two sides: one is fine institutions of governance, stability maintenance of tissue function, the pressure of governance officer. On the other hand is the trend of "involution" phenomenon in the public service is clear [9]; Thirdly, liability subject of risk in it is blur and missing, mainly representing in the serious tendencies of centralized power of governance body, of personal power, of mystical authority, of arbitrary power; Fourthly, culture risks in it are emergent, mainly influenced by capitalist ideology, the feudal autocratic ideology, peasant economy ideology, commodity economy ideology; Finally, the natural ecological risks increase, embodied in energy risks highlighting, testing of resource risk, ecological environmental risks exacerbating, nuclear risks revealing.

The root causes of our social governance innovation's plight is analysed on the horizon of the theory of risk society. There are five root causes of the plight: First, China's market economy in social transition is unique and the imbalances of interests of society in transition are mostly led by economic interests. Second, the risk of social governance system is not perfect led to frequent. The existing social governance system features a unified governance body, fully-oriented governance object, deregulation of governance means and static governance mechanisms. Third, China's social governance is influenced by double risks of development of modernization and social transformation traction. On one hand, modern "space compression" makes all kinds of risks at different periods coexist, on the other hand, rapid social transformation brings about in equalization of interests; Fourth, the consciousness of principal members of our society is weak, mainly in the sense of objects, a latent vassal consciousness, dominate consciousness; Fifth, the background of globalization and the impact of "world risk" bring more and more uncertain risks.

New paths of social governance innovation in China from the perspective of Risk Society Theory should be paid attention to. One path is to reshape social governance values. Chinese characteristic social governance will gradually transform from the present type of object-oriented to people- oriented type, from the rule of man type to the rule of law type, from patriarchal society type to a democratic society type, from the administration type to socialization type. The second path is to innovate social governance philosophy. The main innovation is the establishment of a social risk management concept, the concept of responsibility, social philosophy, the concept of the rule of law, the program concept, and the concept of deliberative democracy. Third, practice new type of social governance. Based on the pattern of "party leadership, government responsibility, social coordination, public participation, to protect the rule of law," the emphasis is laid on nurturing civil society consciousness of community members. Besides, it social organization, to make innovation of grassroots is necessary and enhancing the inspired dynamic community governance system, and gradually to improve the social automatic operating mechanisms. Fourth, construct risk prevention mechanisms of social governance. Firstly, make an innovation of social risk warning mechanism and evaluation mechanisms; Secondly, improve public rights protection mechanism, strive to build a social identity mechanism, to improve the mechanism of interests expression, to deepen social pluralism bidirectional communication mechanism and to improve basic public service system; Fourth, build accountability innovation, including innovating accountability mechanisms of social governance reform mechanisms governance mechanism of checks and balances, and reforming building social development mechanisms; Finally, perfect natural ecological risk governance mechanism, further enhance the governance of ecological environmental risk, adjust energy development strategy, improve the national capital management strategy, establish nuclear security and participate in global ecological risk management actively. Fifth, protect social governance innovation in the rule and thinking of law. By analysing the relationship between social governance and rule of law, we should correctly understand the rule of law and get out of "transformation trap", to resolve "structural tension" of law construction by adopting it. Social governance innovation and the rule of law must be carried out simultaneously. The specific path to the rule of law and innovative ways to promote social governance based on the rule of law and enhance the rule of law and way of thinking norms of social governance decisions, introduction of the system, the use of the rule of law to resolve social conflicts resolve social conflicts, in order to promote the rule of law and civilized way of governance community.

In summary, guided by Marxist scientific world outlook and methodology, dialectically absorbing the experience and practice of social governance innovation from the global risk society theory horizon, this dissertation makes an investigation of "the plight and path of Chinese social governance innovation" and comes to a major conclusion that the process in which we go towards a comprehensive well-off society is a also process in which old and new risks constantly intertwine and interact. In the process of accelerating to the highly developed stage of the modernization, we have to conduct across type of development by the way of "compressed modernization" in order to catch up with the level of industrialization and modernization of hundreds of years of Western society because China is a developing country after exogenous type. It will inevitably be associated with a series 
of "world risk" and social transformation risk. Chinese social governance innovation contains not only a profound look at world risk society, but also a close attention to a series of social transformation risks China has undergone in the context of globalization. Although China doesn't really get into the "high-risk society" stage, we are facing unprecedented risks and challenges and overcoming and resolving risks have become China's most prominent social problems.

Such cases show that our response is that we have to pluck courage to face these risk factors. We should not only take the risk as an important subject for thorough and systematic study, but also pay special attention to the risk problems and their solutions in real life. At the same time, we have to learn "a lesson", because after all, the modern history of the Western capitalist countries is earlier than China and they have practical experience in dealing with risks. Studying the theory of social risk doesn't mean we say no to our characteristic socialist system and the remarkable results of modernization we have already achieved or we are alarmist, pessimistic. We are precautionary and prevent the potential morphology from turning into significant reality by enhancing awareness of risks and dealing with them. It is believed that the Chinese Communist Party may lead all society members to resolving the plight of risk successfully and walking across the stage of risk society by innovating Chinese social governance. Thus, all society members can share the results of the reform and walk towards a better and happy future society.

\section{THE EMPIRICAL RESEARCH BASED ON THE DATA OF A DISTINCT}

A district used to be a famous industrial district. According to national department of civil affairs, by June 2011, the average minimum living guarantee line of people living in urban across the country is $270.48 \mathrm{RMB} /$ month, the numbers of all districts have reached $505 \mathrm{RMB} /$ month. According to the above standard, there are 22.75 million people across the country who can take advantage from the urban minimum living guarantee standard while the number is 339,613$1.49 \%$ of national total.

The number for A district is $32,937,9.7 \%$ of total, and it's the highest figure among all 18 districts except for P district. As a special group of poverties, the number of elder poverties also occupies relatively high proportion-which is $0.84 \%$ in A district. Hence, the need for deep and wide understanding on elder poverties' requirement is now becoming more and more important. In this report, the author conducted relatively deeper investigation into the elder poverties in A district.

Until the end of 2010 , there is totally 446,000 social organizations nationally-3.5\% increment to the previous year. In 2010, the trend of social organization development in A district is very well, and the total number is continuously growing with even larger rates. By 31st Dec. 2010, there are totally 559 different types of social organizations in A district.

In the research, the author conducted surveys on 205 poverties and 60 elder poverties in A district, and took the face to face interview with 8 poverties, 6 elder poverties and 9 officials. This section is composed after author's summari- zation based on the large amount of data and literal response analysed by SPSS and EXCEL.

\section{(1) Overview of social organization}

In the research result, when being asked the satisfactory rate of social organization, more than $70 \%$ poverties selected "generally satisfied" while $9.8 \%$ of people is "very satisfied". In terms of elder poverties, those who selected "very satisfied" accounts for $58 \%$ of total people, and the proportion of people who chose "generally satisfied" is $42 \%$. No one selected "not satisfied", "very unsatisfied" or "not familiar with". It can be seen that the elder poverties have quite high satisfaction rate on social organization. When mentioning the service provided by social organization, lots of poverties respondents complimented very much, and the participation rate of the activities among poverties is quite high, so it can draw the conclusion that currently social organizations have massive people base and expansive development perspective. According to the survey and interview, the author summarized the difficulties encountered by social organizations in their job: relatively less service contents, lack of funding, lack of management, lack of talents, small influence, lack of continuity, lack of related policy support and etc. In the meantime, the author found out from the research that most social organizations providing service for the poverties are basically involved by government such as elders committee, thus governmental background is still apparent. These social organizations can't get out the government background, especially for funding, therefore, they are lack of autonomy and self-governing. Due to the constraint of funding, policy and etc., civil social organizations' survival and development are limited, not even mentioning involving into the job of meeting the requirements of poverties.

(2) Poverties' needs for various services from social organizations

In the research, the author conducted deep research on the conventional seven types of services currently provided by social organizations, which are employment guidance, medical health, children education, legal aid and contradictions mediation, physical \& arts, psychological counselling and elderly service. By investigating whether these seven kinds of services are provided in the poverties respondents' community, whether poverties need those services, and extensive research on each service the author would know the poverties' needs for each service in A district as well as some improvements and modifications to be made to those seven services by social organizations.

By answering the questionnaire, more than $80 \%$ of poverties considered that the social organizations in their community have already provided 4 services including employment guidance, medical health, legal aid and contradictions mediation, and elderly service. By contrast, the offer of children education, physical \& arts and psychological counselling are not in optimistic-more than $40 \%$ of poverties thought these three services are not provided. In the research, the needs of poverties for seven services varies, the Table 1 shows the details. In order to further understand the specific needs of every service for the poverties, some extensive problems related to the seven services except for psychological counselling have been investigated, and Table 2 shows the results of the investigation. 
Table 1. The proportion of poverties and elder poverties who selected "very need or need" (percent, $\%)$.

\begin{tabular}{c|c|c}
\hline Type of service & Poverties & Elder poverties \\
\hline Employment guidance & $89 \%$ & $44 \%$ \\
\hline Medical health & $95 \%$ & $96 \%$ \\
\hline Children education & $80 \%$ & $42 \%$ \\
\hline Legal aid and contradictions mediation & $74 \%$ & $75 \%$ \\
\hline Physical \& arts & $52 \%$ & $82 \%$ \\
\hline Psychological counseling & $61 \%$ & $86 \%$ \\
\hline Elderly service & $66 \%$ & $96 \%$ \\
\hline
\end{tabular}

Table 2. The results of the investigation of every service.

\begin{tabular}{|c|c|}
\hline \multirow{2}{*}{$\begin{array}{l}\text { Employment } \\
\text { guidance }\end{array}$} & Poverties who need this service: Wait for employment $(51.85 \%)$ \\
\hline & Reason why family members can't find a job: Lack of competencies $(60 \%)$ \\
\hline \multirow{5}{*}{ Medical health } & Poverties who need this service: Common physical condition $(65.52 \%)$ \\
\hline & $\begin{array}{l}\text { Ways to treat minor illness (e.g. flu, fever): Won't see a doctor, buy medicine by themselves } \\
(45.95 \%)\end{array}$ \\
\hline & Frequency of taking physical exercises: Usually or occasionally $(73 \%)$ \\
\hline & $\begin{array}{l}\text { Reason why don't take physical exercises: No time }(30 \%) \text {, No site or facilities in community } \\
(30 \%)\end{array}$ \\
\hline & Whether to help own children with their studies: Lack of knowledge, can't help them $(63.94 \%)$ \\
\hline
\end{tabular}

According to summarization and analysis of data attained from survey and interview, the author has deeply understood the main needs for services of poverties and the development status of social organizations in A district. In order to help social organizations to meet the survival and living needs of the poverties as well as find the foothold and emphasis of their services, the author raised suggestions on two aspects based on current status and problem summarized above, which are "exploring emphasis of service and enriching contents of service" and "suggestions for social organizations' self-development".

According to the analysis of the current state, the results in Table $\mathbf{3}$ have the most appealing services of the poverties in A district. We can see that employment guidance, medical health and children education are been summarized. For elder poverties, they need more services of medical health, elderly service, style art and psychological counselling. In the meantime, we can see from the table below that more than $40 \%$ of poverties thinks that the social organizations in their community haven't provided children education, physical $\&$ arts and psychological counselling services currently. From comparison, we can see that children education and psychological counselling services which are more needed services are still deficient in community. Therefore, social organizations need to improve and enrich the services of children education, physical $\&$ arts and psychological counselling on the basis of strengthening functionalities of current services. In the following section, the author will provide detailed suggestions for each of seven services.

(1) Employment guidance. Firstly, this is set to optimize the training policy and improve the training effect. Secondly, governments, related departments and social organizations should establish a unified information sharing platform to promptly provide recruitment information. Thirdly, widening the employment channel and assisting self-employment.

(2) Medical health. On the one hand, charity medical aid should be conducted. Firstly is charity donation. Secondly is regular gratuitous treatment. Thirdly is that local government should organize and take advantage of social resource to establish dedicated charity organizations, which can provide opportunities of physical exercises to poverties by offering appropriate amount of physical equipment, areas for exercises as well as organizing sports shows and matches. On the other hand, social organizations should pay more attention on health education and encourage the poverties to do more physical exercises.

(3) Children education. Firstly, during weekends, summer and winter holidays, it is suggested that social organizations should provide home tutor services to the children of poverties on regular basis such as helping them with English. Secondly, it is recommended that social organizations should provide fixed place for poverties children to study after class which can make them have better environment to finish their homework and review their courses. In the meantime, this is also a good platform for them to communicate their studies to make students studying from others and helping with each other. Thirdly, social organizations with sufficient resources can establish a library in community to provide book reading and borrowing place for children of poverties in the community.

(4) Legal aid and contradictions mediation. On the one hand, community volunteer mediation team should be established. On the other hand, the training for contradiction mediation service team should be strengthened. Moreover, public corridor could be utilized for communication, legal knowledge and contradiction mediation related policies can be hanged on wall with frequent refresh.

(5) Physical \& Arts. First of all, the construction of sports and arts facilities in the community needs to be strengthened. Then, it is important to hunt sports and arts talents and establish sports and arts team. At the end, to strengthen trainings and organize all kinds of activities and contests are also critical. It is recommended to organize regular training for various sports and arts team. In the meantime, large sports and arts events/contests can be held in big holidays. 
Table 3. The comparison between the needs of poverties and the services provide by social organizations.

\begin{tabular}{|c|c|c|c|}
\hline \multicolumn{2}{|c|}{ Major needs of the poverties } & Major needs of the elder poverties & $\begin{array}{l}\text { Services considered not provided by } \\
\text { more than } 40 \% \text { of poverties }\end{array}$ \\
\hline \multicolumn{2}{|c|}{ Medical health $(95 \%)$} & Medical health $(96 \%)$ & Children education $(54 \%)$ \\
\hline \multicolumn{2}{|c|}{ Employment guidance $(89 \%)$} & Elderly service $(96 \%)$ & Physical \& Arts (43\%) \\
\hline \multirow{2}{*}{\multicolumn{2}{|c|}{ Children education $(80 \%)$}} & Psychological counseling (86\%) & Psychological counseling (42\%) \\
\hline & & Physical \& Arts (82\%) & \\
\hline $\begin{array}{l}\text { Children } \\
\text { education }\end{array}$ & \multicolumn{3}{|c|}{$\begin{array}{l}\text { If social organizations can provide free education help for their children: Would like to } \\
\text { participate }(67.21 \%)\end{array}$} \\
\hline \multirow{4}{*}{$\begin{array}{c}\text { Legal aid and } \\
\text { contradictions } \\
\text { mediation }\end{array}$} & \multicolumn{3}{|c|}{ When dispute occurred with neighborhood: Let neighborhoods committee to mediate (37.84\%) } \\
\hline & \multicolumn{3}{|c|}{ Is legal knowledge important: Very important (98\%) } \\
\hline & \multicolumn{3}{|c|}{$\begin{array}{l}\text { Is it necessary to provide legal consultant service in community: It is necessary and must be } \\
\text { free }(62 \%)\end{array}$} \\
\hline & \multicolumn{3}{|c|}{$\begin{array}{l}\text { Whom will be told or reported if there is a problem: Solved by myself or relatives and friends } \\
\qquad(77 \%)\end{array}$} \\
\hline \multirow{2}{*}{ Physical \& arts } & \multicolumn{3}{|c|}{$\begin{array}{l}\text { What do you usually do in relax time : Poverties: Watch TV }(62.30 \%) \text {; Elder poverties: Elder } \\
\text { activities }(56.00 \%)\end{array}$} \\
\hline & \multicolumn{3}{|c|}{$\begin{array}{l}\text { If elder activities center (e.g. cheese and card room) is opened in your community: Would like } \\
\text { to participate }(67.21 \%)\end{array}$} \\
\hline \multirow{4}{*}{ Elderly service } & \multicolumn{3}{|c|}{ Elder poverties who need this service: Living with husband/wife (56.25\%) } \\
\hline & \multicolumn{3}{|c|}{ Is there any social organization or activities majoring in elders in your community: Many (72\%) } \\
\hline & \multicolumn{3}{|c|}{$\begin{array}{l}\text { Opening status of elder activities center (e.g. cheese and card room) in your community: Open } \\
(68.85 \%)\end{array}$} \\
\hline & \multicolumn{3}{|c|}{$\begin{array}{l}\text { Is it necessary for social organization to provide door to door service for elders: Necessary and } \\
\text { free }(62.00 \%)\end{array}$} \\
\hline
\end{tabular}

(6) Psychological counselling. On the one hand, social organizations should initiatively provide psychological consultant service. On the other hand, the poverties should be encouraged to actively seek for psychological consultancy service. Some deeply hidden psychological issues cannot be easily discovered by "community volunteer mediation service team", so it needs them to actively seek for psychological consultant's help by themselves.

(7) Elderly service. For the elder poverties, social organizations should pay more attention to their spiritual culture aspect. Referring to the successful elder services mode of A district $\mathrm{P}$ Street, and according to interview and materials analysis, it is suggested that social organizations should take the following 3 aspects as emphasis. First, they should care for self-living elders. Second, develop house-living retirement and project-like service. Third is to strengthen the management of elder activity room. All these management, maintenance and organization works should be organized by professional social organizations. Therefore, we suggest that in the meantime of improving elder committee's management work, we should also appropriately import other social organizations into the management of elder activity room to ease the workload of elder committees. Moreover, it is suggested that to strengthen the communication and collaboration between the elder activity rooms in different communities, so that they can learn from each other. Other than the three key points mentioned above, most of elder poverties desired the social organizations to provide free door to door service, therefore, social organizations are recommended to improve this type of service. In addition, social organizations can provide related services to to-be-retired elder poverties and non-local elder poverties. Currently, the only social organization focusing on the elders in A district is the elder committees which belong to local communities and have the government background. To some extent, the prospective and space for non-government social organization develop- ment are still quite positive. Therefore, it is suggested that A district should develop more non-governmental social organizations for the elders especially those can provide professional services for elder poverties.

Apart from the above seven services, social organizations can also initiatively explore and add other kinds of services, e.g. convenience services (help for bathing, hair cutting and etc.). Furthermore, social organizations should also pay attention to those poverties of non-local residents, returning people et al. to provide appropriate services.

Great efforts should be made to further promote China's social structure, quicken the pace of separating the government from social organizations, foster and create channels and mechanism for social organizations to enter public sphere and improve citizens' social construction. All these should be treated as a vital decision-making of the government and the CPC for the purpose of achieving the scientific concept of development. Great efforts should be made to further define and detail the functions of government departments; the government administrative departments are responsible for macro decision-making and part of the supervision function and should gradually hand over some micro supervision function to social organizations when implementing the function. We should bear in mind and call for the idea of "the government buys service", the concrete implementations are to entrust and grant, contracts, and invitation of public bidding, etc.

In accordance with the principles of "comprehensive arrangement, separation of the government from social organizations, classified guidance, steady implementation", administrative departments of the government and relevant organs taking charge of the administration of social organizations should strengthen the guidance and aid, scientific administration and standardization for the conducts of social organizations, and support them in working according to laws and respective regulations. Donation is the primary source of 
funds for social organizations, and donators can enjoy the preferential tax policy according to Law of the People's Republic of China on Donations for Public Welfare, but this is not workable. Thus workable implementation measures should be formulated. Social organizations should keep making explorations and improving on the mechanism and action pattern suitable for the law of their own development, practice strict self-discipline, enhance trust in them from the public so as to lay a good foundation for them to assume the shift of government functions.

Professional organizations are encouraged and supported in assuming the role of verification of making decisions, professional consultation, formulation of standards and criterions, demonstration and evaluation of projects, social rewards, certification of professional qualifications and evaluation of talents, education and training, and maintenance of professional morality, etc. We shall launch the organizational work for China's entry into international mutual recognition of engineering qualifications as early as possible, and establish the committee of international mutual recognition of engineering qualifications which is mainly participated in by professional organizations. Respective functions of both the government and social organizations should be clearly defined from the level of laws and regulations, and we should treat the shift of functions according to law as the basis and approach of the shift of government function. The formulation of laws and regulations for administration of social organizations should be quickened, and thus helping to clearly define the legal status and relevant social roles for various social organizations such as mass organizations or grass-rooted societies, industry associations, etc.

\section{CONCLUSION}

This paper has shown the influence of people demand oriented social governance and organizations based on the theory of risk society. Professional organizations are encouraged and supported in assuming the role of verification of making decisions, professional consultation, formulation of standards and criterions, demonstration and evaluation of projects, social rewards, certification of professional qualifications and evaluation of talents, education and training, and maintenance of professional morality, etc. We shall launch the organizational work for China's entry into international mutual recognition of engineering qualifications as early as possible, and establish the committee of international mutual recognition of engineering qualifications which is mainly participated in by professional organizations.

\section{CONFLICT OF INTEREST}

The author confirms that this article content has no conflict of interest.

\section{ACKNOWLEDGEMENTS}

This work is supported by the Chongqing higher education teaching reform research key project, China (No.142065), and the Chongqing social sciences planning (Dr, cultivating) project, China (No, 2014BS038).

\section{REFERENCES}

[1] C. Ana, "Ethics and supervision process - fundaments of social work practice", Procedia - Social and Behavioral Sciences, 2013, 92.

[2] B. Eda, and Y. Buğra, "Human rights as a dimension of social work education", Procedia - Social and Behavioral Sciences, vol. 106, 2013.

[3] V. Vasintha, "Reframing the discourse on social work in the Arab World: considerations for the accreditation of social work in the UAE", Social Work Education, 328, 2013.

[4] T.C. Jason, B. David, L. Kwangyeop, and K.R. Anish, "The role of the government in addressing social issues in India: the perceptions of Indian undergraduate and graduate social work students", Social Work Education, 331, 2014.

[5] P. Marianne, S. Marijke, L. Caroline, and R. Nol, "Legitimizing social work: the practice of reflective professionals", Journal of Social Intervention : Theory and Practice, 193, 2010.

[6] L. Ione, B. Natalie, "Social work with a twist: interweaving practice knowledge, student experience and academic theory", Australian Social Work, 602, 2007,.

[7] R. Akashi, H. Akashi, "Social work in international health and medical assistance", BioScience Trends, 24, 2008.

[8] D. Brigid, "Social work: a profession in flux", Journal of Workplace Learning, 256, 2013.

[9] C. Ani, S. Ejiofor, "Ethicalization of social work and socialization of ethics-an african challenge", Open Journal of Political Science, $0502,2015$.

\author{
Received: June 10, 2015 \\ Revised: July 29, 2015 \\ Accepted: August 15, 2015 \\ (C) Feihu Li; Licensee Bentham Open.
}

This is an open access article licensed under the terms of the (https://creativecommons.org/licenses/by/4.0/legalcode), which permits unrestricted, noncommercial use, distribution and reproduction in any medium, provided the work is properly cited. 